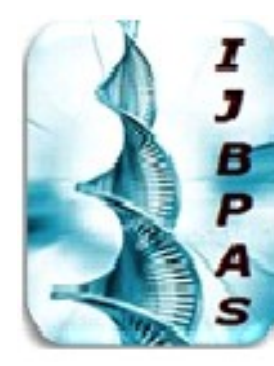

International Journal of Bhology, Pharmacy and Allied Sciences (IJBPAS) 'A B Bridge Betusen Cabratory and QRendo'

Www.iibpas.com

\title{
FORMULATION AND CHARACTERIZATION OF IBUPROFEN -
}

\section{ALOEVERA TRANSEMULGEL}

\author{
E ANUSHA $^{1 *}$, MADHU GUDIPATI ${ }^{2}$ AND RAMA RAO NADENDLA ${ }^{3}$ \\ Department of Pharmaceutics, Chalapathi Institute of Pharmaceutical Sciences, (Autonomous), \\ Lam, Guntur, Andhra Pradesh-522 034, India \\ *Corresponding Author: E Anusha: E Mail: anushaemineni0406@gmail.com \\ Received 11 ${ }^{\text {th }}$ March 2021; Revised 10 ${ }^{\text {th }}$ April 2021; Accepted 10 ${ }^{\text {th }}$ May 2021; Available online $1^{\text {st }}$ Jan. 2022

\section{https://doi.org/10.31032/IJBPAS/2022/11.1.5827}

\begin{abstract}
To develop an ibuprofen Transemulgel gel with a capability for both topical and systemic drug delivery. Aloe vera is most popular in treatment of dermatologist disorder in acne of burn, tan and wound healing. The study was designed for crude Aloe vera extract, development of oil in water $(\mathrm{o} / \mathrm{w})$ emulsion, preparation of gel base using Aloe vera extract and formulation of the emulgel for topical application.The formulation was prepared by using Ibuprofen (NSAID) and propylene glycol as permeation enhancer.The $\mathrm{pH}$ and viscosity of the aloe vera emulgel were noticed to be 7.2 and 750 centipose (cps) respectively. The interaction study between photochemical and the excipients was carried out using Fourier transform infrared (FTIR) Spectroscopy. UV spectrometric analysis of plant extract was carried out respectively.

Keywords: Transemulgel, Aloevera gel, Ibuprofen, Fourier transform infrared (FTIR) spectroscopy
\end{abstract}

\section{INTRODUCTION}

The main objective of transdermal drug delivery system is to deliver drugs into systemic circulation into the skin through skin at predetermined rate with minimal inter and intra patient variation. Currently transdermal delivery is one of the most promising methods for drug application. It enhances patient compliances and minimizes 
harmful side effects of a drug caused from temporary over dose and is convenience in transdermal delivered drugs that require only once weakly application [1].

\subsection{Properties that influence transdermal delivery}

2. Release of the medicament from the vehicle.

3. Penetration through the skin barrier.

4. Activation of the pharmacological response.

\subsection{Advantages of transdermal drug delivery}

- Transdermal drug delivery enables the avoidance of gastrointestinal absorption with its associated pitfalls of enzymatic and $\mathrm{pH}$ associated deactivation.

- Avoidance of first pass metabolism.

\subsection{EMULGEL}

As the name suggest, they are the combination of gel and emulsion. Both oilin-water and water-in-oil type of emulsion used as a vehicle to deliver various drugs to the skin. They also have a high ability to penetrate the skin. The presence of the gelling agent in water phase converts a classical emulsion into an emulgel [2]. Emulgel for dermatological use has several favorable properties such as being thixotropy, greaseless, easily spreadable, easily removable, emollient, non-staining, water-soluble, longer shelf life, bio-friendly, transparent and pleasing appearance.

\subsection{ANALGESICS}

Pain \& Pain Management: Pain can be defined as a somatic sensation of acute discomfort, a symptom of some physical hurt or disorder, or even emotional distress. Pain is a crucial aspect of the body's defense mechanisms $\&$ it is a part of a rapid warning relay instruction the motor neurons of the central nervous system to minimize physical harm [5]. Pain can be classified into two types: a) Acute pain b) Chronic pain

a) Acute pain: Acute pain 'is the body's warning of present damage to tissue or disease', It is often fast and sharp followed by aching pain. It is short-term pain or pain with easily identifiable causes.

b) Chronic Pain: Chronic pain is pain that last much longer than pain normally would with a particular injury. Chronic pain can be constant or intermittent and is generally harder to treat than acute pain.

\section{PLANT PROFILE}

Species: Aloe Barbadense

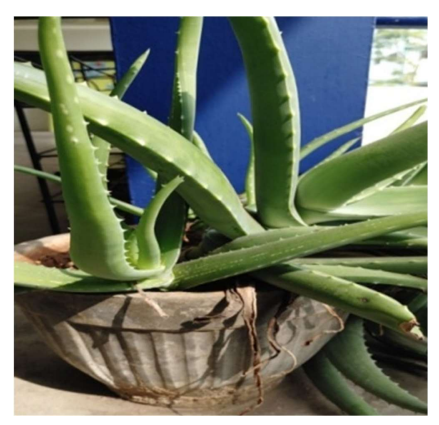

Figure 1: ALOE VERA 
Molecular Formula: $\mathrm{C}_{16} \mathrm{H}_{13} \mathrm{NO}_{3}$

Molecular Weight: 267.27932

Category: Softening agent, Permeation

enhancer, Anti-inflammatory

\subsection{PHYSICAL AND CHEMICAL PROPERTIES}

Colour: Slightly yellow

Odour: Objectionable

Taste: Bitter

\subsection{Uses}

It is used as a purgative [3]

$>$ It has laxative property and may help to treat constipation.

$>$ It is used in treating skin conditions, such as psoriasis and acne.

$>$ Aloe creams have a calming effect on skin and have been shown to help reduce itchiness.

Aloe vera also shows an anti-inflammatory action.

\section{MATERIALS AND METHODS}

\section{PREFORMULATION STUDIES}

Preformulation testing is the first step in rational development of dosage forms of a drug substance [4]. It can be defined as an investigation of physical and chemical properties of a drug substance alone and when combined with excipients. Preformulation studies were performed for the obtained sample of drug for identification and compatibility studies.

Following studies are conducted as basic preformulation studies:

- Organoleptic properties

- Identification of ibuprofen

- Solubility.

- Compatibility studies

Table 1: Instruments used

\begin{tabular}{|c|c|c|}
\hline S. No. & Instrument & Model number \\
\hline 1 & UV/VIS spectrophotometer & Systronics, India \\
\hline 2 & FTIR & Bruker, Germany \\
\hline 3 & Electronic Balance & Systronics, India \\
\hline 4 & Magnetic stirrer & Remi equipment, Pvt. Ltd. \\
\hline
\end{tabular}

Table 2: Chemicals Used

\begin{tabular}{|c|c|c|}
\hline S. No & Chemicals & Brand \\
\hline 1. & Ibuprofen & Yarrow chemical products, Mumbai \\
\hline 2. & Carbopol 940 & Rolex chemical industries, Mumbai \\
\hline 3. & Carbopol 934 & Yarrow chemical products, Mumbai \\
\hline 4. & Na CMC & Merck specialties Pvt.Ltd, Mumbai \\
\hline 5. & Tween 80 & RFCL Ltd, New Delhi \\
\hline 6. & Span 80 & Fallav chemicals and solutions pvt. Ltd, Boisar \\
\hline 7. & Liquid paraffin & Karnataka fine chemicals, Banglore \\
\hline 8. & Propylene glycol & Finar Ltd, Ahmedabad, Gujarat \\
\hline 9. & Triethanolamine & Pallav chemicals and solvents pvt.Ltd, Boisar \\
\hline 10. & Propyl paraben & Pallav chemicals and solvents pvt. Ltd, Boisar \\
\hline 11. & Methyl paraben &
\end{tabular}




\subsection{PREPARATION OF STANDERD PLOT OF DRUG}

\subsubsection{In phosphate buffer 5.5:}

Drug equivalent $100 \mathrm{mg}$ was accurately weighed and dissolved in $100 \mathrm{ml}$ of phosphate buffer 5.5 the volume was made up to the mark with buffer 5.5. To make concentration $1000 \mu \mathrm{g} / \mathrm{ml}$ (stock solution' a') from stock solution (a)10ml was dissolved again $100 \mathrm{ml}$ volumetric flask to make concentration $100 \mu \mathrm{g} / \mathrm{ml}$ stock solution in (b) aliquots $2 \mathrm{ml}, 4 \mathrm{ml}, 6 \mathrm{ml}, 8 \mathrm{ml}, 10 \mathrm{ml}, 12 \mathrm{ml}$ of stock solution ' $b$ ' where pipette out and final volume was made to $100 \mathrm{ml}$ with buffer 5.5 to get concentration of $2 \mu \mathrm{g} / \mathrm{ml}, 4 \mu \mathrm{g} / \mathrm{ml}, 6 \mu \mathrm{g} / \mathrm{ml}$, $8 \mu \mathrm{g} / \mathrm{ml}, 10 \mu \mathrm{g} / \mathrm{ml}, 12 \mu \mathrm{g} / \mathrm{ml}$ respectively the absorbance (Graph 1).

\section{EXTRACTION OF ALOEVERA GEL} (Figure 2)

The central parenchymatous pulp was scooped out with a spatula from the ALOE leaves and the pulp was washed repeatedly with water and finally treated with $0.1 \mathrm{~N}$ sodium hydroxide to avoid the acidity [5]

$>$ The treated pulp was placed in a blender to obtain the juice.

$>$ The obtained juice was subjected to vacuum filtration.

$>$ To the clear liquid so obtained, $1 \% \mathrm{w} / \mathrm{w}$ Carbopol 934 was added and dispersed uniformly ensuring no lumps.
A $0.5 \mathrm{~N} \mathrm{NaOH}$ solution was added drop wise until a gel was formed.

The prepared aloe vera gel was weighed and stored in air tight containers in a dark room to prevent photo-oxidation.

\subsection{Preparation of drug Emulgel (Figure 3)}

\subsection{STEP -1:}

$\checkmark$ The oil phase of the emulsion was prepared by dissolving span 80 in liquid paraffin while the aqueous phase was prepared by dissolving Tween 80 in purified water [1]

$\checkmark$ Methyl and Propyl Parabens were dissolved in propylene glycol whereas ibuprofen was dissolved in ethanol, and both solutions were mixed to aqueous phase.

$\checkmark$ Both the oily and aqueous phases were separately heated to $70^{\circ}-80^{\circ} \mathrm{C}$ then the oily phase was added to the aqueous phase with continuous stirring until cooled to room temperature.

\subsection{STEP-2:}

$\checkmark$ In the preparation of emulgel first we go for the preparation of gel base, Carbopol 934 is the commonly used gel formers and at low concentration it forms good consistency transparent gel. It will be prepared by dispersing Carbopol 934 in distilled water [6] While dispersing Carbopol into distilled water, aloe vera 
gel and clove oil are also added and soak it for $24 \mathrm{hrs}$.

$\checkmark \quad$ The same procedure is followed for the preparation of gel bases i.e., Carbopol 940 and sodium CMC without adding Aloevera gel and clove oil.

\subsection{STEP-3}

$\checkmark$ The obtained emulsion was mixed with the gel base in 1:1 ratio with gentle stirring to obtain the emulgel.

$\checkmark$ Finally, $\mathrm{pH}$ of emulgel was adjusted by using triethanolamine.

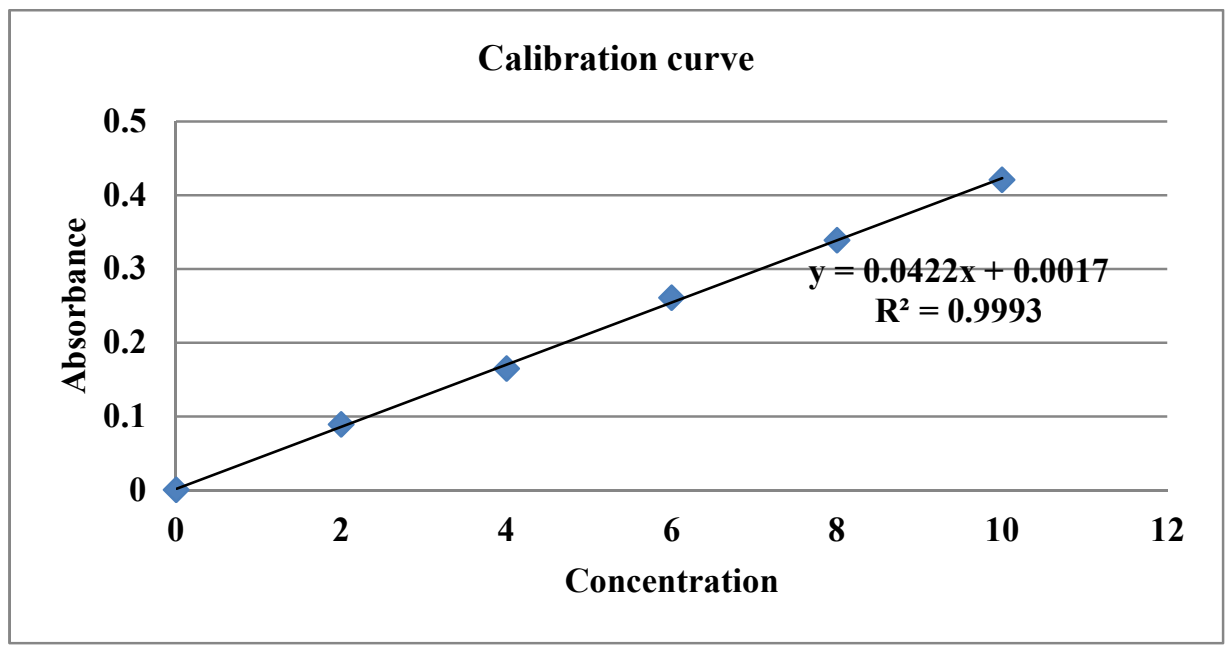

Graph 1: Calibration curve for Ibuprofen

Table 3: Standard Curve of Drug

\begin{tabular}{|c|c|c|}
\hline S. No. & CONCENTRATION & ABSORBANCE \\
\hline 1 & 2 & 0.089 \\
\hline 2 & 4 & 0.165 \\
\hline 3 & 6 & 0.261 \\
\hline 4 & 8 & 0.339 \\
\hline 5 & 10 & 0.421 \\
\hline
\end{tabular}

Table: 4 Formulation of Transemulgel

\begin{tabular}{|c|c|c|c|c|c|c|c|c|c|}
\hline Ingredients & F1 & F2 & F3 & F4 & F5 & F6 & F7 & F8 & F9 \\
\hline Carbapol934 & 1 & 1.2 & 1.5 & - & - & - & - & - & - \\
\hline Carbapol940 & - & - & - & 0.5 & 1.0 & 1.5 & - & - & - \\
\hline Na CMC & - & - & - & - & - & - & 5 & 5.5 & 6 \\
\hline Ibuprofen & 0.5 & 0.5 & 0.5 & 0.5 & 0.5 & 0.5 & 0.5 & 0.5 & 0.5 \\
\hline Span80 & 0.5 & 0.5 & 0.5 & 0.5 & 0.5 & 0.5 & 0.5 & 0.5 & 0.5 \\
\hline Tween80 & 1 & 1 & 1 & 1 & 1 & 1 & 1 & 1 & 1 \\
\hline Liquid Paraffin & 7.5 & 7.5 & 7.5 & 7.5 & 7.5 & 7.5 & 7.5 & 7.5 & 7.5 \\
\hline Triethanolamine & & & Adjust & The & pH & from & 5.5 to & 6.5 & \\
\hline Propyl Paraben & 0.01 & 0.01 & 0.01 & 0.01 & 0.01 & 0.01 & 0.01 & 0.01 & 0.01 \\
\hline Methyl paraben & 0.03 & 0.03 & 0.03 & 0.03 & $\mathbf{0 . 0 3}$ & 0.03 & 0.03 & 0.03 & 0.03 \\
\hline Aloe vera (1\%) & 1 & 2 & 3 & - & - & - & - & - & - \\
\hline Purified Water & 100 & 100 & 100 & 100 & 100 & 100 & 100 & 100 & 100 \\
\hline Clove Oil & - & - & - & 7 & 7.5 & 8 & - & - & - \\
\hline Propylene glycol & 5 & 5 & 5 & 5 & 5 & 5 & 5 & 5 & 5 \\
\hline
\end{tabular}




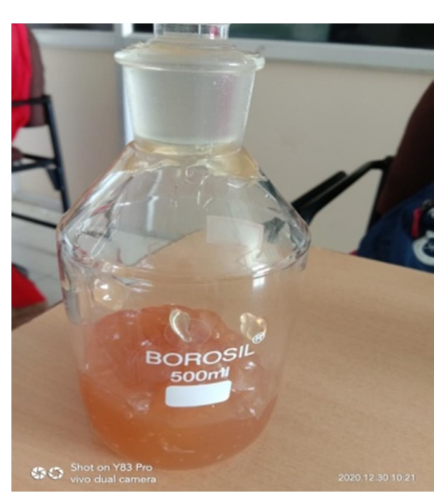

Figure 2: Extraction of Aloevera Gel

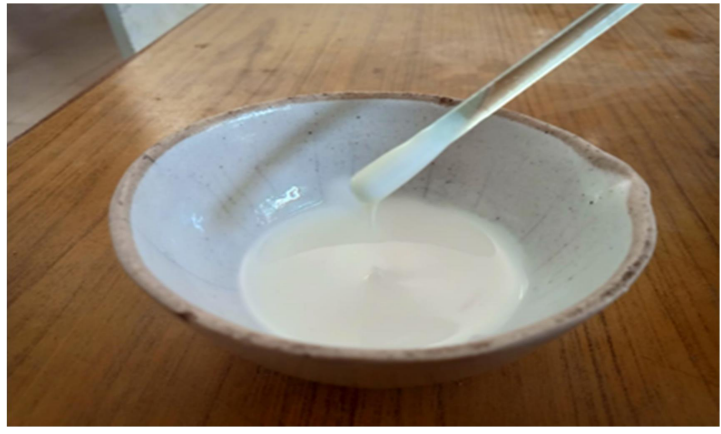

F-1 Formulation

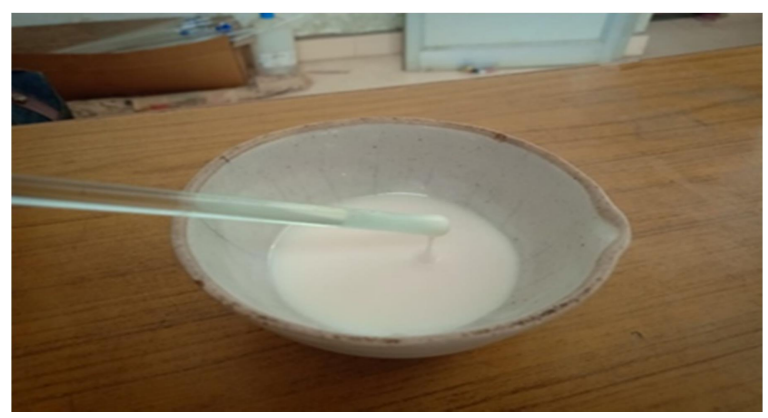

F-4Formulation

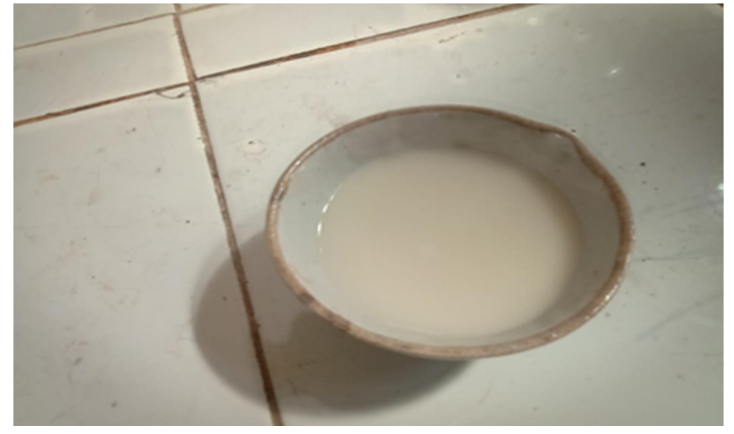

F-2 Formulation

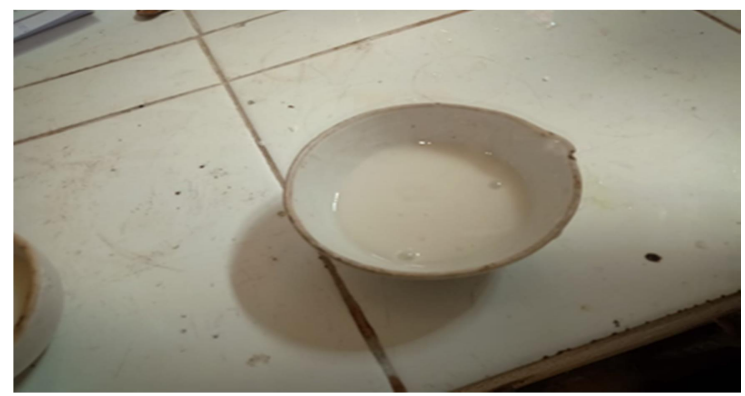

F-5 Formulation

Figure 3: Emulgel Preparations

6. CHARACTERIZATION OF EMULGEL

\subsection{PHYSICAL EXAMINATION}

The prepared emulgel formulations were inspected visually for their color, homogeneity, consistency, grittiness and separation.

\subsection{MEASUREMENT OF pH}

The $\mathrm{pH}$ of emulgel formulation was determined by using digital $\mathrm{pH}$ meter. One gram of gel was dissolved in $100 \mathrm{ml}$ of distilled water and stored for 2 hours [7] The measurement of $\mathrm{pH}$ of each formulation was done in triplicate and average values were calculated.

\subsection{SWELLING INDEX}

It is determined by taking $1 \mathrm{~g}$ of emulgel in a porous aluminum foil and mixed with $0.1 \mathrm{~N}$ $\mathrm{NaOH}$ kept in a $50 \mathrm{ml}$ beaker. These samples 
are withdrawn at different time intervals and kept for drying and it is reweighed. Swelling index is calculated as follows:

Swelling index $=\{$ Wt. - Wo/Wo $\} 100$

where, (SW) $\%=$ Equilibrium percent swelling,

$W_{t}=$ weight of swollen emulgel after time "t'"

$W_{t .}=$ weight of emulgel at zero time.

\subsection{SPREADABILITY}

$\checkmark$ It is measured in terms of diameter of emulgel circle produced when emulgel is placed between two glass plate of definite weight.

$\checkmark$ Weighed quantity (350mg) of emulgel is taken on one glass plate and another glass plate is dropped from a distance of $5 \mathrm{~cm}$

$\checkmark$ Diameter of circle of spread emulgel is measured.

\subsection{DRUG CONTENT}

$\checkmark$ Emulgel is mixed in a suitable solvent. Filter it to obtain clear solution.
Determine its absorbance using UV spectrophotometer [17] From the standard equation by putting the absorbance value concentration and drug content can be obtained [8]

$\checkmark$ Drug Content $=($ Concentration $\times$ Dilution Factor $\times$ Volume taken) $\times$ Conversion Factor.

\subsection{In-vitro DRUG RELEASE STUDIES}

Franz diffusion cell is used for the study. Emulgel is applied on the surface of egg membrane is clamped between the donor \& the receptor chamber of diffusion cell. The receptor chamber contains freshly prepared PBS (pH5.5) solution to solubilize the drug. The receptor chamber is stirred using magnetic stirrer [9] The samples $(1.0 \mathrm{ml}$ aliquots) are collected at different time intervals and analyzed for drug content by us-vis spectrophotometer after asppropriate dilutions. Drug release is based on a function of time [16]

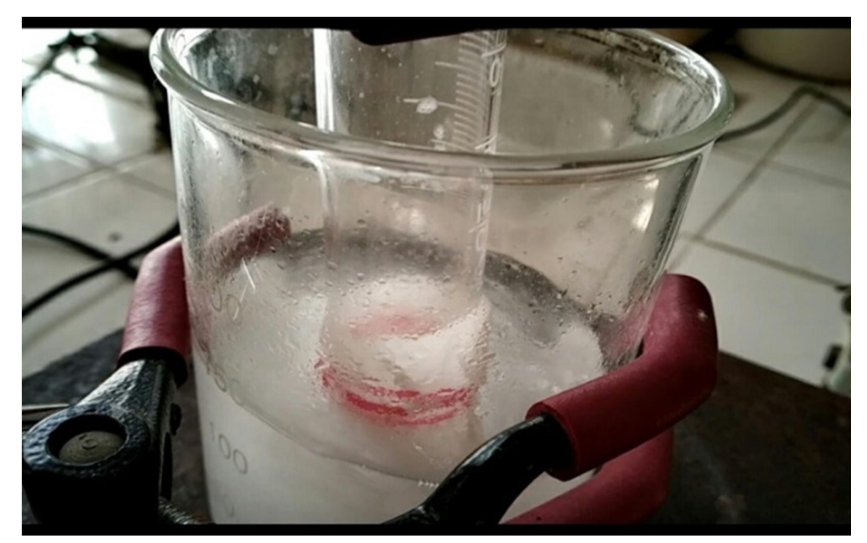

Figure 4: In-vitro drug release studies 


\section{RESULTS AND DISCUSSION}

\subsection{A Physical appearance:}

The prepared Transemulgel appear as white dispersion because the drug itself is colorless and doesn't observe any phase separation [9]

\subsection{B Weight of Transemulgel:}

$50 \mathrm{ml}$ of aloe vera juice was utilized to make formulation which yielded a weight of 47.85 g. $50 \mathrm{ml}$ of emulsion was utilized to make formulation which yielded a weight of $47.54 \mathrm{~g}$.

\subsection{Measurement of $\mathrm{pH}$ :}

$\mathrm{P}^{\mathrm{H}}$ for formulation was found to be 6.98 where marketed gel showed 7.17 [10]

\subsection{Viscosity:}

Viscosity of the prepared formulation was found to be 17 cps [11] less viscosity may indicate that it requires addition of viscosity building agents to improve its stability [12]

\subsection{E Drug content:}

Drug content for the formulation was 84.3 $\mathrm{mg}$ in $100 \mathrm{~g}$ of Transemulgel [13] whereas commercial gel (ibuprofen aloe vera emulgel IAE) showed $89.5 \mathrm{mg}$ in $100 \mathrm{~g}$ of gel [14].

\subsection{F Permeation studies:}

The permeation of ibuprofen aloe vera Transemulgel through the membrane has revealed the flux of emulgel as 0.0174 where the permeability coefficient of emulgel was 0.00174 and enhancement ratio of Transemulgel was 1.104 for IAE and 1.054 for CIG (Commercial ibuprofen gel) when compared with the pure drug [15].

Table 5: Viscosity, $\mathrm{pH}$ and diffusion characteristics of the emulgel

\begin{tabular}{|c|c|c|c|c|c|}
\hline Formulation & Viscosity (cps) & $\mathbf{p H}$ & $\%$ drug content & $\begin{array}{l}\text { Flux }(\mu \mathrm{g} \\
\mathrm{cm}^{-2} \mathbf{h}^{-1)}\end{array}$ & $\begin{array}{c}\text { Permeability } \\
\text { coefficient }\left(\mathrm{cm} \mathrm{h}^{-1}\right)\end{array}$ \\
\hline Plain emulgel & $70+0.48$ & $6.83+0.68$ & - & - & - \\
\hline IAE & $17+0.98$ & $6.98+[0.79$ & $84.4+-1.21$ & 0.0174 & 0.00174 \\
\hline CAG & & $7.17+0.53$ & 89.5+_0.94 & 0.016 & 0.00106 \\
\hline
\end{tabular}

\subsection{DISCUSSION}

Aloevera has variety of skin elements such as mild cuts along with skin moisturizing and anti-aging, digestive tract health, blood and lymphatic circulation and functioning of kidney. Aloevera from being an antiseptic it also acts as anti-inflammatory [16]. Ibuprofen aloe vera Transemulgel was prepared by mixing the equal proportion of gel base with emulsion [17]. All the formulations were colorless preparations with a homogenous [18].

\section{ACKNOWLEDGEMENT}

The authors would like to thank professor Rama Rao Nadendla principal \& Dr Madhu Gudipati, Head of the Department, for providing facilities and for their support in my research work. 


\section{REFERENCES}

[1] Kullar R, Saini S, steth N, Rana AC, Emulgel a surrogate approach for topical used hydrophobic drugs, Int-J-Pharm Biosci 2011: 1: 117-28.

[2] MC Grath JA, Eady R \& Pope Fm, Chapter 3 anatomy and organizatiosn of huaman skin, P 3.1.3.15.

[3] Kumar L, verma R, invitro evaluation of topical gel prepred using natural polymer Int journal of drug delivery 2010; 2; 8-63.

[4] Emanuel LL, Von Gunten CF, Ferris FD. Module 4 Pain Management. The Education for Physicians on End-of-life Care (EPEC) curriculum, 1999; 1-37.

[5] Husni T, Hantash AEJ.Evaluation of Narcotic (Opioid Like) Analgesic Activities of Medicinal Plants. European Journal of Scientific Research, ISSN 1450-216X Vol.33 No.1 2009, 179-182.

[6] Snehal P. Mulye, Kiran A. Wadkar and Manish B Kondawar, Pelagia Research Library 2013, 4(5): 31-45.

[7] Rachit Khullar, Deepinder Kumar, Nimrata seth, Seema saini. 2011.08.001.

[8] Kalpesh Ashara, Moinuddin M. Soniwala, Ketan Shah. V, (2016) 26(3); 244-249.

[9] Magdy, Mohamed. AAPS Journal 6(3): e26 Journal of Advanced Pharmaceutical Technology and Research, 2004.
[10]Joshi Baibhav, Singh Gurpreet, Rana AC, Saini Seema, August (2012) I.J.D.D $\& \mathrm{R}$.

[11]S.Z. Chemate, Rahul M. Anbhule Feb 28, 2017.

[12]Emam A. Khalil, Samia A. Majid, Ghadeer A.R.Y. Suaifan, Faisal T. AlAkayleh 2015.

[13]Yan Shen, Xiang Ling, Shuang Du, Jiasheng TU 2014.

[14]Abhishek Bansal, Sanjay Singh, M.A. Salaeem and Savim Imran 2015.

[15]Dhobale, Shankar, Shelke Gajanan, Jadhav Suresh, Gaikward Dushyant 2018.

[16]A.V. Pakhare, S.V. Deshmane, S.S. Deshmane, K.R. Biyani 11(4) /S712 2018.

[17]Nitin Prabhakar Ambhok, Panchaxari, Mallapa Dandagi, Anand Panchaxari Gadad, Paresh Mandora, Indian Journal of pharmaceutical education and research 51(4): 525-535.

[18] Shailendra Panwar, Satyantan Mukhopadhyay, Preeti Kothiyal, American Journal of Pharmaceutical Technology Research, 2015 6/56037. 